\title{
Changes in Biochemical Properties of Fresh Attiéké During Its Storage
}

\author{
Sahoré drogba alexis ${ }^{*}$, Nemlin Gnopo Jean \\ Food Science and Technology Department University Abobo- Adjamé, 02BP801 Abidjan02. Ivory Coast
}

\begin{abstract}
Samples of attiéké, food on base of cassava, were kept in various temperatures namely: $\left(30^{\circ} \mathrm{C}\right),\left(15^{\circ} \mathrm{C}\right),\left(6^{\circ} \mathrm{C}\right)$ and $\left(-18^{\circ} \mathrm{C}\right)$ during 15 days to study the changes of its biochemical properties according to the duration of the storage. at $30^{\circ}$ $\mathrm{C}$, under ambient conditions, attiéké fermented rapidly after 3 to 4 days, at $15^{\circ} \mathrm{C}$ in the cold room and $6^{\circ} \mathrm{C}$ in the refrigerator the fermentation occurred in the first 10 days. During storage at these positive temperatures, the biochemical properties of attiéké varied significantly. Furthermore, the biochemical properties of attiéké kept at $-18^{\circ} \mathrm{C}$ in the freezer has not changed much, except his taste became flat. The attiéké kept at- $18^{\circ} \mathrm{C}$ in the freezer does not ferment after 15 days.
\end{abstract}

Keywords AttiÉKÉ, Cassava, Storage, Biochemical Properties

\section{Introduction}

The roots and tubers have considerable importance in the food of numerous African populations[1] It is the case of the cassava (Manihot esculenta Crantz) which is typical in developing countries[2]. The root of cassava is the raw material of the preparation of Attiéké, a traditional meal of Ivory Coast[3].

The preparations with bases of cassava are varied and numerous, the most complex aim is eliminating its bitterness and its toxicity.

The fermentation is used in numerous traditional transformation technologies of cassava roots[4]. Attiéké is the cassava fermentation product. It is a kind of couscous of cassava to slightly acid taste.

Its moisture content is enough raised (40\% f.m) and its preserving does not exceed one week. However attiéké is a meal much appreciated by the inhabitants of the Ivory Coast, particularly by the coastal population of the country for which it constitutes the staple food[5]. The object of our paper is to estimate preserving duration of fresh attiéké at various temperatures and to know how evolve physical and biochemical properties of the product

\section{Material and Methods}

For this study we used as material, attiéké bought on the market of Abidjan.

*Corresponding author

alexissahore@yahoo.fr(Sahoré drogba alexis)

Published online at http//journal.sapub.org / fph

Copyright (C) 2012 Scientific \& Academic Publishing, All Rights Reserved
It shows the following characteristics: - white colour, -slightly acid taste, - odours of flour, - does not stick on the touched. 3 sample of attiéké of $300 \mathrm{~g}$ each one contained in the bags of cellophane are placed at various temperatures $\left(-18^{\circ} \mathrm{C}\right)$; $\left(6^{\circ} \mathrm{C}\right)$; $\left(15^{\circ} \mathrm{C}\right)$; $\left(30^{\circ}\right)$ and the biochemical modifications are followed over 2 weeks

The following methods are used: Water content by desiccation with the drying oven of the sample at $105^{\circ} \mathrm{C}$ until constant weight[6], ash content is determined by incineration with the muffle furnace of the sample at $650^{\circ} \mathrm{C}[6]$, total sugars content are determined by Luff Schoorl iodometric method[7], total carbohydrates are determined by difference, starch content is calculated starting from the percentage of total carbohydrates and total sugars. Acidity is determined with solution of $\mathrm{NAOH} 0.1 \mathrm{~N}$ in the presence of phenolphthalein[6]

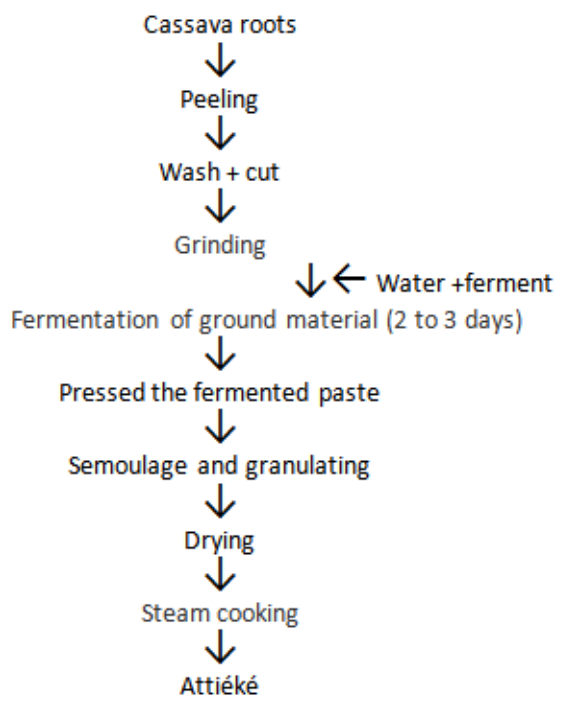

Figure 1. Diagram of the traditional preparation attiéké 


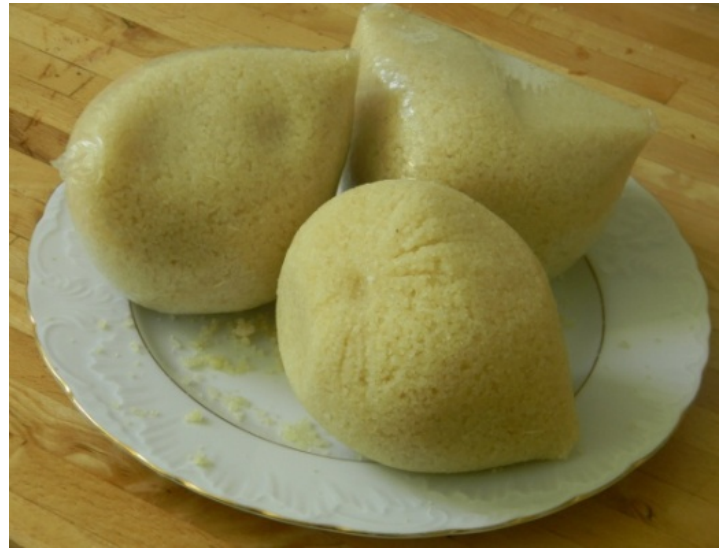

Figure 2. Attiéké ball set

\section{Results}

Table 1 shows biochemical characteristics of Attiéké kept at $30^{\circ} \mathrm{C}$ outdoors.

After 5 days storage at ambient temperature $\left(30^{\circ} \mathrm{C}\right)$, samples smell bad, have a slight browning and are sticky to touch. Biochemical properties have varied.

Moisture content of the product decreases from $52.50 \pm$ $0.02 \%$ f.m to $49.50 \pm 0.10 \%$ f.m. Ash content increased from $0.62 \pm 0.02 \%$ to $0.89 \pm 0.10 \% \mathrm{f} . \mathrm{m} ; \mathrm{pH}$ value ranged from 4.11 to \pm 0.01 to $4.15 \pm 0.05$ and titratable acidity ranged from $2.43 \pm 0.01 \mathrm{meq} / 100 \mathrm{~g}$ f.m to $0.80 \pm 0.00 \mathrm{meq} /$
$100 \mathrm{~g}$ f.m; sugar content varied from $7.64 \pm 0.80 \%$ f.m to $9.96 \pm 1.10 \%$ f. m; starch content ranged from $39.47 \pm$ $0.50 \%$ f. $\mathrm{m}$ to $38.53 \pm 0.50 \% \mathrm{f}$. $\mathrm{m}$; total carbohydrate content ranged from $51.50 \pm 2.30 \% \mathrm{f}$. $\mathrm{m}$ to $51.77 \pm 0.90 \%$ f.m

After 10 days, there is a swelling of container and appearance of mold on the samples. Moisture content of product ranged from $52.50 \pm 0.02 \% \mathrm{f}$. $\mathrm{m}$ to $50.50 \pm 0.04 \% \mathrm{f}$. $\mathrm{m}$; ash content ranged from $0.62 \pm 0.02 \%$ to $0.46 \pm 0.04 \%$ f.m; $\mathrm{pH}$ value ranged from $4.11 \pm 0.01$ to $4.20 \pm 0.07$ and the acidity ranged from $2.43 \pm 0.01 \mathrm{meq} / 100 \mathrm{~g}$ f.m to $2.0 \pm$ $0.01 \mathrm{meq} / 100 \mathrm{~g}$ f.m; sugar content ranged from $7.64 \pm$ $0.80 \%$ f.m to $16.41 \pm 0.40 \%$ f. $\mathrm{m}$; starch content ranged from $39.47 \pm 0.50 \%$ f.m to $27.78 \pm 0.08 \%$ f.m; total carbohydrates decreased slightly in the product.

After 15 days, samples were fermented and they smell bad. Moisture content of product ranged from $52.50 \pm 0.02 \%$ f.m to $51.50 \pm 0.05 \%$ f.m; ash content ranged from $0.62 \pm$ $0.02 \%$ f.m to $0.39 \pm 0.00 \%$ f.m; pH ranged from $4.11 \pm$ 0.01 to $4.34 \pm 0.11$; titratable acidity ranged from $2.43 \pm 0.01$ meq / $100 \mathrm{~g}$ f.m to $2.46 \pm 0.00 \mathrm{meq} / 100 \mathrm{~g}$ f.m; total sugar content ranged from $7.64 \pm 80 \%$ f.m to $19.59 \pm 2.30 \%$ f.m; starch content ranged from $39.47 \pm 0.50 \%$ f.m to $23.76 \pm$ $0.42 \%$ f.m; total carbohydrates content decreased slightly in the product. It ranged from $51,50 \pm 2.30 \%$ f.m to $45.94 \pm$ $0.24 \%$ f.m

Table 1. Biochemical properties of Attiéké

\begin{tabular}{|c|c|c|c|c|c|c|c|c|}
\hline $\begin{array}{l}\text { Storage } \\
\text { duration } \\
\text { (days) }\end{array}$ & $\begin{array}{l}\text { Sample stor- } \\
\quad \text { age } \\
\text { Temperature }\end{array}$ & $\begin{array}{l}* \text { Moisture } \\
* *(\% \text { f.m) }\end{array}$ & $\begin{array}{c}\text { *Ashes } \\
* * \text { (\%f.m) }\end{array}$ & *pH & $\begin{array}{c}* \text { Acidity } \\
* * *(\mathrm{meq} \\
/ 100 \text { g f.m })\end{array}$ & $\begin{array}{c}* \text { Total } \\
\text { sugars } \\
* *(\% \text { f.m })\end{array}$ & $\begin{array}{c}\text { *Total } \\
\text { Carbohydrates } \\
* *(\% \text { f.m })\end{array}$ & $\begin{array}{c}* \text { Starch } \\
* *(\% \text { f.m })\end{array}$ \\
\hline 0 & $\left(28\right.$ à $\left.30^{\circ} \mathrm{C}\right)$ & $52.5 \pm 0.02$ & $0.62 \pm 0.02$ & $\begin{array}{c}4.11 \pm \\
0.01\end{array}$ & $2.43 \pm 0.01$ & $7.64 \pm 0.80$ & $51.50 \pm 2.30$ & $\begin{array}{l}39.47 \\
\pm 0.50\end{array}$ \\
\hline 5 & $30^{\circ} \mathrm{C}$ & $49.50 \pm 0.10$ & $0.89 \pm 0.10$ & $\begin{array}{c}4.15 \pm \\
0.05\end{array}$ & $0.80 \pm 0.00$ & $9.96 \pm 1.10$ & $51.77 \pm 0.90$ & $\begin{array}{l}38.53 \\
\pm 0.50\end{array}$ \\
\hline 10 & $30^{\circ} \mathrm{C}$ & $50.50 \pm 0.40$ & $0.46 \pm 0.04$ & $\begin{array}{c}4.20 \pm \\
0.07\end{array}$ & $2.00 \pm 0.01$ & $\begin{array}{l}16.41 \\
\pm 0.40\end{array}$ & $47.27 \pm 0.12$ & $\begin{array}{l}27.78 \\
\pm 0.08\end{array}$ \\
\hline 15 & $30^{\circ} \mathrm{C}$ & $51.50 \pm 0.05$ & $0.39 \pm 0.00$ & $\begin{array}{c}4.34 \pm \\
0.11\end{array}$ & $2.46 \pm 0.00$ & $\begin{array}{l}19.59 \\
\pm 2.30\end{array}$ & $45.94 \pm 0.24$ & $\begin{array}{l}23.76 \\
\pm 0.42\end{array}$ \\
\hline
\end{tabular}

*The value in each column represents the mean of three determinations 
Table 2 shows the biochemical characteristics of attiéké kept at $15^{\circ} \mathrm{C}$ in a cold room.

After 5 days, the biochemical characteristics have varied slightly (Table 2), the product aspect remained stable. Moisture content of product ranged from $52.50 \pm 0.02 \% \pm$ 0.20 f.m to $53.0 \%$ f.m; ash content ranged from $0.62 \pm$ $0.02 \%$ f.m to $0.81 \pm 0.01 \%$ f.m; $\mathrm{pH}$ value ranged from 4.11 \pm 0.01 to $4.11 \pm 0.10$ and titratable acidity ranged from 2.43 $\pm 0.01 \mathrm{meq} / 100 \mathrm{~g}$ f.m to $2.30 \pm 0.05 \mathrm{meq} / 100 \mathrm{~g}$ f.m; sugar content ranged from $7.64 \pm 0.80 \%$ f.m to $11.60 \pm 0.08 \%$ f.m; starch content ranged from $39.47 \pm 0.50 \%$ fm to $35.34 \pm$ $0.06 \%$ f.m ; total carbohydrate content has varied little.

After 10 days, samples smell bad and have a moldy taste. They are sticky to touch. Biochemical characteristics have varied.

Moisture content ranged from $52.50 \pm 0.02 \%$ to $53.50 \pm$ $0.50 \%$ f.m; ash content ranged from $0.62 \pm 0.02 \%$ f.m to $0.59 \pm 0.01 \%$ f.m; $\mathrm{pH}$ value ranged from $4.11 \pm 0.01$ to 4.20 \pm 0.02 and titratable acidity ranged from $2.43 \pm 0.01 \mathrm{meq} /$ $100 \mathrm{~g}$ f.m to $2.0 \pm 0.01 \mathrm{meq} / 100 \mathrm{~g} \mathrm{f.m}$; the sugar content ranged from $7.64 \pm 0.80 \%$ f.m to $16.16 \pm 0.40 \%$ f. m; starch content ranged from $39.47 \pm 0.50 \%$ f.m to $30.55 \pm 1.70 \%$ fm; total carbohydrates decreased slightly in the produit.de 51.50 $\pm 2.30 \%$ f.m to $50.11 \pm 0.60 \%$ f.m.

After 15 days, samples were fermented and smell bad. Moisture content of product ranged from $52.50 \pm 0.02 \%$ f.m to $53.50 \pm 0.00 \% \mathrm{f} . \mathrm{m}$; ash content ranged from $0.62 \pm$ $0.02 \%$ f.m to $0.49 \pm 0.03 \%$ f.m; pH ranged from $4.11 \pm$ 0.01 to $4.26 \pm 0.09$; the titratable acidity ranged from $2.43 \pm$ $0.01 \mathrm{meq} / 100 \mathrm{~g}$ f.m to $1.40 \pm 0.06 \mathrm{meq} / 100 \mathrm{~g}$ f.m; Total sugar content ranged from $7.64 \pm 80 \%$ f.m to $15.01 \pm 0.20 \%$ f. $\mathrm{m}$; starch content ranged from $39.47 \pm 0.50 \% \mathrm{fm}$ to 32.40 $\pm 0.17 \%$ f.m; total carbohydrates content decreased slightly in the product of $51,50 \pm 2.30 \%$ f.m at $50.20 \pm$ $0.09 \%$ f.m
Table 3 shows the biochemical characteristics of Attiéké kept at $6{ }^{\circ} \mathrm{C}$ in the refrigerator.

After 5 days, the biochemical characteristics have varied slightly (Table 3 ), the product aspect has remained stable.

Moisture content of product ranged from $52.50 \pm 0.02 \%$ f.m to $54.0 \pm 0.01 \%$ f.m; ash content ranged from $0.62 \pm$ $0.02 \%$ f.m to $0.79 \pm 0,00 \%$ f. $\mathrm{m} ; \mathrm{pH}$ value ranged from $4.11 \pm 0.01$ to $4.11 \pm 0.00$ and titratable acidity ranged from $2.43 \pm 0.01 \mathrm{meq} / 100 \mathrm{~g}$ f.m to $2.29 \pm 0.00 \mathrm{meq} / 100 \mathrm{~g}$ f.m; sugar content ranged from $7.64 \pm 0.80 \%$ f.m to $19.59 \pm$ $0.07 \%$ f.m; starch content ranged from $39.47 \pm 0.50 \%$ f.m to $34.24 \pm 0.35 \% \mathrm{f} . \mathrm{m}$; the total carbohydrate content has varied little after five days at $6{ }^{\circ} \mathrm{C}$.

After 10 days, samples have an insipid taste. Biochemical characteristics have varied.

Moisture content ranged from $52.50 \pm 0.02 \%$ f.m to 53.00 $\pm 0.00 \%$ f.m; ash content ranged from $0.62 \pm 0.02 \%$ to 0.58 $\pm 0.01 \%$ f.m; $\quad \mathrm{pH}$ value ranged from 4.11 to $0.01 \pm 4.20$ to \pm 0.00 and titratable acidity ranged from $2.41 \pm 0.01 \mathrm{meq} /$ $100 \mathrm{~g}$ f.m to $2.0 \pm 0.08 \mathrm{meq} / 100 \mathrm{~g}$ f.m; the sugar content ranged from $7.64 \pm 0.80 \%$ f.m to $15.98 \pm 1.20 \%$ f.m ; starch content ranged from $39.47 \pm 0.50 \%$ f.m to $31.37 \pm 0.08 \%$ f.m; total carbohydrate content was unchanged (table 3 ).

After 15 days, the samples slightly fermented smell bad and are sticky to touch and have not changed color.

Moisture content of product ranged from $52.50 \pm 0.02 \%$ f.m to $53.30 \pm 0.02 \%$ f. $\mathrm{m}$; ash content ranged from $0.62 \pm$ $0.02 \%$ f.m to $0.48 \pm 0.00 \%$ f.m; $\mathrm{pH}$ ranged from $4.11 \pm$ 0.01 to $4.20 \pm 0.04$; the titratable acidity ranged from $2.43 \pm$ $0.01 \mathrm{meq} / 100 \mathrm{~g}$ f.m to $1.39 \pm 0.02 \mathrm{meq} / 100 \mathrm{~g}$ f.m; the total sugar content ranged from $7.64 \pm 80 \%$ fm to $15.00 \pm 0.09 \%$ f.m; starch content ranged from $39.47 \pm 0.50 \%$ f.m to 32.40 $\pm 0.14 \%$ f.m; total carbohydrates content decreased slightly in the product of $51,50 \pm 2.30 \% \pm 0.16 \mathrm{f}$. $\mathrm{m}$ to $50.20 \%$ f.m

Table 2. Biochemical properties of Attiéké

\begin{tabular}{|c|c|c|c|c|c|c|c|c|}
\hline $\begin{array}{l}\text { Storage } \\
\text { duration } \\
\text { (days) }\end{array}$ & $\begin{array}{c}\text { Sample } \\
\text { storage } \\
\text { Temperature }\end{array}$ & $\begin{array}{l}* \text { Moisture } \\
* *(\% \text { f.m) }\end{array}$ & $\begin{array}{l}\text { *Ashes } \\
* *(\% \text { f.m) }\end{array}$ & *pH & $\begin{array}{l}\text { *Acidity } \\
* * *(\mathrm{meq} \\
/ 100 \text { g f.m })\end{array}$ & $\begin{array}{c}* \text { Total } \\
\text { sugars } \\
* *(\% \text { f.m })\end{array}$ & $\begin{array}{c}\text { *Total } \\
\text { Carbohydrates } \\
* *(\% \text { f.m })\end{array}$ & $\begin{array}{c}* \text { Starch } \\
* * \text { (\% f.m) }\end{array}$ \\
\hline 0 & $\left(28\right.$ à $\left.30^{\circ} \mathrm{C}\right)$ & $52.5 \pm 0.02$ & $0.62 \pm 0.02$ & $\begin{array}{c}4.11 \pm \\
0.01 \\
\end{array}$ & $2.43 \pm 0.01$ & $7.64 \pm 0.80$ & $51.50 \pm 2.30$ & $\begin{array}{c}39.47 \pm \\
0.50 \\
\end{array}$ \\
\hline 5 & $15^{\circ} \mathrm{C}$ & $53.0 \pm 0.20$ & $0.81 \pm 0,01$ & $\begin{array}{c}4.11 \pm \\
0.10\end{array}$ & $2.30 \pm 0.05$ & $\begin{array}{c}11.60 \pm \\
0.08\end{array}$ & $50.87 \pm 1.40$ & $\begin{array}{c}35.34 \pm \\
0.06\end{array}$ \\
\hline 10 & $15^{\circ} \mathrm{C}$ & $53.50 \pm 0.50$ & $0.59 \pm 0.01$ & $\begin{array}{c}4.14 \pm \\
0.02\end{array}$ & $2.41 \pm 0.00$ & $\begin{array}{c}16.16 \pm \\
0.08\end{array}$ & $50.11 \pm 0.60$ & $\begin{array}{c}30.55 \pm \\
1.70 \\
\end{array}$ \\
\hline 15 & $15^{\circ} \mathrm{C}$ & $53.0 \pm 0.00$ & $\begin{array}{c}0.49 \pm \\
0.03\end{array}$ & $\begin{array}{c}4.26 \pm \\
0.09\end{array}$ & $1.40 \pm 0.06$ & $\begin{array}{c}15.01 \pm \\
0.20\end{array}$ & $50.20 \pm 0.09$ & $\begin{array}{c}32.40 \pm \\
0.17\end{array}$ \\
\hline
\end{tabular}

*The value in each column represents the mean of three determinations

** (\% f.m): \% fresh matter

$* * *(\mathrm{meq})$ : milliequivalent 
Table 3. Biochemical properties of Attiéké

\begin{tabular}{|c|c|c|c|c|c|c|c|c|}
\hline $\begin{array}{l}\text { Storage } \\
\text { duration } \\
\text { (days) }\end{array}$ & $\begin{array}{l}\text { Sample stor- } \\
\quad \text { age } \\
\text { Temperature }\end{array}$ & $\begin{array}{l}* \text { Moisture } \\
* *(\% \text { f.m })\end{array}$ & $\begin{array}{l}\text { *Ashes } \\
* *(\% \text { f.m) }\end{array}$ & ${ }^{*} \mathrm{pH}$ & $\begin{array}{l}\text { *Acidity } \\
* * *(\text { meq } \\
/ 100 \text { g f.m) }\end{array}$ & $\begin{array}{c}* \text { Total } \\
\text { sugars } \\
* *(\% \text { f.m })\end{array}$ & $\begin{array}{c}\text { *Total } \\
\text { Carbohydrates } \\
* *(\% \text { f.m })\end{array}$ & $\begin{array}{c}* \text { Starch } \\
* *(\% \text { f.m })\end{array}$ \\
\hline 0 & $\left(28\right.$ à $\left.30^{\circ} \mathrm{C}\right)$ & $52.5 \pm 0.02$ & $0.62 \pm 0.02$ & $\begin{array}{c}4.11 \pm \\
0.01 \\
\end{array}$ & $2.43 \pm 0.01$ & $7.64 \pm 0.80$ & $51.50 \pm 2.30$ & $\begin{array}{c}39.47 \pm \\
0.50 \\
\end{array}$ \\
\hline 5 & $6^{\circ} \mathrm{C}$ & $54.0 \pm 0.01$ & $0.79 \pm 0.00$ & $\begin{array}{c}4.11 \pm \\
0.00\end{array}$ & $2.29 \pm 0.00$ & $\begin{array}{c}19.59 \pm \\
0.07\end{array}$ & $51.03 \pm 0.75$ & $\begin{array}{c}34.24 \pm \\
0.35\end{array}$ \\
\hline 10 & $6^{\circ} \mathrm{C}$ & $53.0 \pm 0,00$ & $0.58 \pm 0.00$ & $\begin{array}{c}4.13 \pm \\
0.00 \\
\end{array}$ & $2.41 \pm 0.08$ & $\begin{array}{c}15.98 \pm \\
1.20 \\
\end{array}$ & $51.20 \pm 0.40$ & $\begin{array}{c}31.37 \pm \\
0.08 \\
\end{array}$ \\
\hline 15 & $6^{\circ} \mathrm{C}$ & $53.30 \pm 0.02$ & $0.48 \pm 0.00$ & $\begin{array}{c}4.20 \pm \\
0.04 \\
\end{array}$ & $1.39 \pm 0.02$ & $15.0 \pm 0.09$ & $50.20 \pm 0.01$ & $\begin{array}{l}32.40 \\
\pm 0.14 \\
\end{array}$ \\
\hline
\end{tabular}

*The value in each column represents the mean of three determinations ** (\% f.m): \% fresh matter $* * *$ (meq): milliequivalent

Table 4 shows biochemical characteristics of Attiéké kept at $\left(-18{ }^{\circ} \mathrm{C}\right)$ in the freeze.

After 5 days, samples of attiéké, which had a slightly acidic taste, became insipid and have a crystallized structure. Moisture content of product ranged from $52.50 \pm 0.02 \%$ f.m to $51.0 \pm 0.03 \%$ f.m; ash content ranged from $0.62 \pm 0.02 \%$ f.m to $0.85 \pm 0.05 \%$ f.m; $\mathrm{pH}$ value ranged from 4.11 to \pm 0.01 to $4.11 \pm 0.04$ and titratable acidity ranged from $2.43 \pm$ $0.01 \mathrm{meq} / 100 \mathrm{~g}$ f.m to $2.41 \pm 0.07 \mathrm{meq} / 100 \mathrm{~g} \mathrm{f.m}$; sugar content ranged from $7.64 \pm 0.80 \%$ f.m to $10.61 \pm 0.05 \%$ f.m; starch content ranged from $39.47 \pm 0.50 \%$ f.m to $36.80 \pm$ $1.00 \%$ f.m ; total carbohydrates content did not change after five days at $18{ }^{\circ} \mathrm{C}$.

After 10 days, moisture content ranged from $52.50 \pm 0.02 \%$ f.m to $51.00 \pm 0.00 \% \mathrm{f}$. $\mathrm{m}$; ash content ranged from $0.62 \pm$ $0.02 \%$ f.m to $0.46 \pm 0.02 \%$ f.m; $\mathrm{pH}$ value ranged from $4.11 \pm 0.01$ to $4.13 \pm 0.01$ and titratable acidity ranged from
$2.43 \pm 0.01 \mathrm{meq} / 100 \mathrm{~g}$ f.m to $2.40 \pm 0.03 \mathrm{meq} / 100 \mathrm{~g}$ f.m; the sugar content ranged from $7.64 \pm 0.80 \%$ f.m to $13.91 \pm$ $0.00 \%$ f.m; starch content ranged from $39.47 \pm 0.50 \%$ f.m to $32.58 \pm 0.11 \%$ f.m; the total carbohydrates content was little change in the product. (Table 4 )

After 15 days, moisture content of the product ranged from $52.50 \pm 0.02 \%$ f.m to $50.00 \pm 0.00 \%$ f.m; ash content ranged from $0.62 \pm 0.02 \mathrm{f}$. $\mathrm{m}$ to $0.40 \% \pm 0.05 \%$ f.m; $\mathrm{pH}$ ranged from $4.11 \pm 0.01$ to $4.20 \pm 0.04$; the titratable acidity ranged from $2.43 \pm 0.01 \mathrm{meq} / 100 \mathrm{~g}$ f.m to $2.46 \pm 0.04 \mathrm{meq} /$ $100 \mathrm{~g}$ f.m;

total sugars content ranged from $7.64 \pm 80 \%$ f.m to 15.00 $\pm 0.00 \%$ f.m; starch content ranged from $39.47 \pm 0.50 \%$ f. m to $32.40 \pm 0.41 \% \mathrm{f}$. $\mathrm{m}$; the content of total carbohydrates decreased slightly in the product of $51,50 \pm 2.30 \%$ f.m to $50.20 \pm 0.01 \%$ f.m.

Table 4. Biochemical properties of Attiéké

\begin{tabular}{|c|c|c|c|c|c|c|c|c|}
\hline $\begin{array}{l}\text { Storage } \\
\text { duration } \\
\text { (days) }\end{array}$ & $\begin{array}{c}\text { Sample } \\
\text { storage } \\
\text { Temperature }\end{array}$ & $\begin{array}{l}* \text { Moisture } \\
* *(\% \text { f.m })\end{array}$ & $\begin{array}{l}\text { *Ashes } \\
* *(\% \text { f.m) }\end{array}$ & $*_{\mathrm{pH}}$ & $\begin{array}{c}* \text { Acidity } \\
* * * \text { (meq } \\
/ 100 \text { g f.m) }\end{array}$ & $\begin{array}{c}\text { *Total } \\
\text { sugars } \\
* *(\% \text { f.m) }\end{array}$ & $\begin{array}{c}\text { *Total } \\
\text { Carbohydrate } \\
* *(\% \text { f.m })\end{array}$ & $\begin{array}{c}* \text { Starch } \\
* *(\% \text { f.m })\end{array}$ \\
\hline 0 & $\left(30^{\circ} \mathrm{C}\right)$ & $52.5 \pm 0.02$ & $0.62 \pm 0.02$ & $4.11 \pm 0.01$ & $2.43 \pm 0.01$ & $7.64 \pm 0.80$ & $51.50 \pm 2.30$ & $\begin{array}{c}39.47 \pm \\
0.50\end{array}$ \\
\hline 5 & $-18^{\circ} \mathrm{C}$ & $51.0 \pm 0.03$ & $0.85 \pm 0,05$ & $4.11 \pm 0.04$ & $2.41 \pm 0.07$ & $\begin{array}{c}10.61 \pm \\
0.05 \\
\end{array}$ & $51.50 \pm 1.90$ & $\begin{array}{c}36.80 \pm \\
1.00 \\
\end{array}$ \\
\hline 10 & $-18^{\circ} \mathrm{C}$ & $51.0 \pm 0,00$ & $0.46 \pm 0.02$ & $4.13 \pm 0.01$ & $2.40 \pm 0.03$ & $\begin{array}{c}13.91 \pm \\
0.00 \\
\end{array}$ & $50.11 \pm 0.14$ & $\begin{array}{c}32.58 \pm \\
0.11 \\
\end{array}$ \\
\hline 15 & $-18^{\circ} \mathrm{C}$ & $50.0 \pm 0.00$ & $0.40 \pm 0.05$ & $\begin{array}{c}4.20 \pm \\
0.04\end{array}$ & $2.46 \pm 0.04$ & $15.0 \pm 0.00$ & $50.20 \pm 0.01$ & $\begin{array}{l}32.40 \\
\pm 0.41\end{array}$ \\
\hline
\end{tabular}

*The value in each column represents the mean of three determinations ** (\% f.m): \% fresh matter

$* * *(\mathrm{meq})$ : milliequivalents 


\section{Discussion}

The limited sealing of packaging used, the high moisture content of sample and the temperature of $\left(30^{\circ} \mathrm{C}\right)$ storage are factors that favor the microorganism development responsible for rapid alteration organoleptic properties and biochemical properties of samples of attiéké.

The fresh samples perspire and lose water at room temperature $\left(30^{\circ} \mathrm{C}\right)$.

Until the fifth day, the samples attiéké sweat and lose water. That could explain the lowering of the water content during the first days of conservation with $30^{\circ} \mathrm{C}$

Beyond the fifth day, respiratory activity of the sample stopped, they fermented and leading to an increase of moisture content[8]. As from 10th day, perspiration made place with the fermentation which will cause the gaseous emission and of the heat[9].

During this fermentation, microorganisms (endogenous and exogenous) will degrade starch and nitrogen compounds in sugars and organic acids. This will provide a decrease in starch content, and increased levels of of total sugars and titratable acidity[9].

Kinetics of rate variation of ashes, or rather the dry matter during the storage, inversely proportional to the variation moisture content in samples attiéké. This explains the increase until the fifth day, the rate of ashes and its lowering the following days[11].

Preservation at low temperature $\left(15^{\circ} \mathrm{C} ; 6^{\circ} \mathrm{C}\right)$ inhibits some micro-organisms and delays the fermentation of the sample.

Positive cold slows the enzymatic reactions and the development of microorganisms. It prolongs the life of fresh produce by limiting their alteration this could explain the slight variations biochemical parameters of samples, contrary to what was found in the case of storage at ambient temperature $\left(30^{\circ} \mathrm{C}\right)$.

The samples are frozen at $\left(-18^{\circ} \mathrm{C}\right)$; this low temperature reduces kinetics of many biochemical reactions and the low water activity including its crystallization.

Enzymatic reactions are only slowed. Development of microorganisms is stopped. All these factors explain the very slightest variations in biochemical parameters analyzed in the study

At $\left(-18^{\circ} \mathrm{C}\right)$ the biochemical properties, of the sample, did not vary too much. Activity of water was blocked and there is inhibition of any microbial development[10]. That blocks deterioration of the physical properties and biochemical of the sample

\section{Conclusions}

According to our results, the low temperature and preferably negative cold $\left(-18^{\circ} \mathrm{C}\right)$ seems best suited for conservation attiéké costs. Despite the problem of taste loss that was found.
The biochemical properties of attiéké kept in- $18^{\circ} \mathrm{C}$ did not change a lot.

And the development of the microflora, the cause of the fermentation, increase in the positive temperatures, was inhibited during the freezing.

The negative temperature seems to be a method of conservation best indicated for this perishable food at short-term

\section{ACKNOWLEDGEMENTS}

We thank Cedric Sahoré, a student at the University of Leiden (Netherlands), for help in English.

\section{REFERENCES}

[1] Terry E R, Doku EU, Arene OB, Mahungu NM. Plantes Racines Tropicales : Culture et emplois en Afrique 1983.

[2] Kohou F, Michel P. Céréales en régions chaudes; Conservation et transformation. Ed. John Libbey Eurotext. London, Paris. 1988

[3] Aboua F. A simple Technique for the Product of Dehydrates Attiéké in Rural Area in Côte d'Ivoire.Trop. Sci, 1989; 29, $39-45$.

[4] Anonyme. Rapport du Comité Technique Restreint. Ministère l'Education Nationale et de la Recherche Scientifique 1985.

[5] Kouadio NA, Angbo SF, Mosso K. Etude Comparative, Méthodes de Préparations Traditionnelles de l'attiéké dans le sud de la Côte d'Ivoire. Industries Alimentaires et Agricoles 1991; 108:703-706

[6] Association of Official Analytical Chemist. "Official Methods of Analysis," $11^{\text {th }}$ Edition. Arlington VA, USA: 1980.

[7] Bureau Interprofessionnel d'Etude Analytique. Recueil des Méthodes d'Analyse des Communautés Européennes. Gennevilliers, France : 1976.

[8] Muchnik J, Vinck D. La transformation du manioc. Technologies Autochtones, Paris France : Presses Universitaires de France 1983.

[9] Amoa Awua WKA, Jakobsen M. The role of Bacillus species in the fermentation of cassava Journal of Applied Bacteriology $1995 ; 79,250-256$

[10] Zoumenou V. Etude Physicochimique et Nutritionnelle de Quelques Préparations Alimentaires à base de Manioc ( $\mathrm{Ma}$ nihot esculenta Crantz). Thesis, University of Cocody, Abidjan, 1994, pp.1-102

[11] Sahoré D.A, Nemlin G.J, Kamenan A. Changes in nutritional properties of yam (dioscorea spp), plantain (Musa spp) and cassava(Manihot esculenta) during storage Trop. Sci.2007,47(2),81-88 